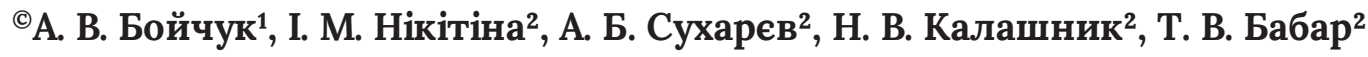 \\ ${ }^{1}$ ДВНЗ «Тернопільський державний медичний університет \\ ілені І. Я. Горбачевсъкого МОЗ України» \\ ${ }^{2}$ Сумсъкий державний університет
}

\title{
МОЖЛИВОСТІ ЛІКУВАННЯ ЗАГРОЗИ ПЕРЕДЧАСНИХ ПОЛОГІВ ПРИ БАГАТОПЛІДНІЙ ВАГІТНОСТІ $З$ ВИКОРИСТАННЯМ СУБЛІНГВАЛЬНОЇ ФОРМИ МIКРОНІЗОВАНОГО ПРОГЕСТЕРОНУ
}

\begin{abstract}
Мета дослідження - оцінити ефрективність застосування сублінгвальної фрорми мікронізованого прогестерону (Лютеіна) у жінок із багатоплідною вагітністю з високим ризиком загрози передчасних пологів.

Матеріали та методи. Обстежено 85 вагітних із двійнятами з ознаками невиношування у термінах 22-36 тижнів вагітності, котрі склали основну групу, ссрормовано дві підгрупи: Іа - 43 жінки, котрі отримували в комплексі лікування загрози передчасних пологів мікронізований прогестерон сублінгвально; підгрупа Іб - 42 вагітні, які не отримували під час лікування препарати прогестерону. Ретроспективно було проаналізовано 40 історій передчасних пологів при одноплідній вагітності (група порівняння). В основній групі було проведено загальноклінічне та біохімічне обстеження вагітних, визначення вмісту в сироватці крові АЛТ, АСТ, рівнів білірубіну та прогестерону. Проведений аналіз перебігу вагітності, пологів, післяпологового періоду та стану неонатальної адаптації новонароджених в обстежуваних вагітних.

Результати дослідження та їх обговорення. Доведені основні чинники ризику розвитку передчасних пологів при багатоплідній вагітності, а також роль інсекційного анамнезу, даних трансвагінальної цервікометрії, неповного обстеження та несвоєчасного початку лікування загрози передчасних пологів, недостатньої профрілактики ускладнень при багатоплідній вагітності. Динаміка вкорочення шийки матки була значно повільнішою у пацієнток Іа підгрупи, яким було призначено мікронізований прогестерон, це є есрективним методом профрілактики та лікування невиношування у жінок із багатоплідною вагітністю, зниження частоти пізнього аборту та передчасних пологів, перинатальних втрат. Встановлено, що в жінок основної групи рівні АЛТ та АСТ, а також загального білірубіну не відхилялися від норми. Відмічено зниження рівня прогестерону в обох підгрупах. У вагітних Іа підгрупи на тлі лікування мікронізованим прогестероном відмічалося суттєве зростання рівня прогестерону у сироватці крові вже на 3-тю добу лікування до (1109 27) нмоль/л, а до кінця першого тижня лікування цей показник

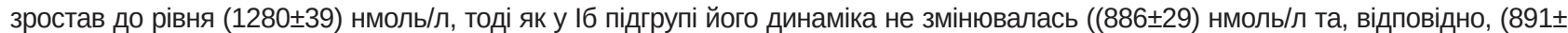
33) нмоль/л). Використання сублінгвальної фрорми мікронізованого прогестерону у період вираженої клінічної симптоматики загрози передчасних пологів при багатоплідній вагітності дозволяє отримати максимально швидкий терапевтичний ефрект, що сприяє швидкому усуненню клінічних симптомів, регресу ультразвукових маркерів загрози переривання вагітності та запобігає подальшому прогресуванню структурних змін з боку шийки матки.

Висновки. 1. При ознаках загрози передчасних пологів застосування сублінгвальної фрорми мікронізованого прогестерону дає можливість швидко відновити рівень прогестерону в сироватці крові до фрізіологічних показників і тим самим знизити частоту передчасних пологів та покращити перинатальні наслідки у новонароджених. 2. Застосування сублінгвальної фрорми мікронізованого прогестерону у вагітних із загрозою передчасних пологів не впливає на фрункцію печінки. 3. Комплексна терапія загрози передчасних пологів із використанням мікронізованого прогестерону має високу есективність терапевтичної дії та може бути рекомендована для широкого використання, сприяє коротшому періоду перебування в стаціонарі, зменшенню кількості ускладнень.
\end{abstract}

Ключові слова: багатоплідна вагітність; невиношування; сублінгвальна форма мікронізованого прогестерону (Лютеіна); вагінальна фрорма мікронізованого прогестерону; загроза передчасних пологів.

ВОЗМОЖНОСТИ ЛЕЧЕНИЯ УГРОЗЫ ПРЕЖДЕВРЕМЕННЫХ РОДОВ ПРИ МНОГОПЛОДНОЙ БЕРЕМЕННОСТИ С ИСПОЛЬЗОВАНИЕМ СУБЛИНГВАЛЬНОЙ ФОРМЫ МИКРОНИЗИРОВАННОГО ПРОГЕСТЕРОНА

Цель исследования - оценить эффрективность применения сублингвальной фрормы микронизированного прогестерона (Лютеина) у женщин с многоплодной беременностью с высоким риском угрозы преждевременных родов.

Материалы и методы. Обследовано 85 беременных с двойней с признаками невынашивания в сроке 22-36 недель беременности, которые составили основную группу, сорормированы две подгруппы: Іа - 43 женщины, которые получали в комплексе лечения угрозы прерывания беременности микронизированный прогестерон сублингвально; подгруппа Іб - 42 беременные, которые не получали во время лечения препараты прогестерона. Ретроспективно были проанализированы 40 историй преждевременных родов при одноплодной беременности (группа сравнения). В основной группе было проведено общеклиническое и биохимическое обследование беременных, определение содержания в сыворотке крови АЛТ, АСТ, уровней билирубина и прогестерона. Проведен анализ течения беременности, родов, послеродового периода и состояния неонатальной адаптации новорожденных в обследуемых беременных.

Результаты исследования и их обсуждение. Доказаны основные фракторы риска развития преждевременных родов при многоплодной беременности, а также роль инфекционного анамнеза, данных трансвагинальной цервикометрии, неполного обследования и несвоевременного начала лечения угрозы преждевременных родов, недостаточной просилактики осложнений при многоплодной беременности. Динамика укорочения шейки матки была значительно медленнее у пациенток Іа подгруппы, которым был назначен микронизированный прогестерон, это является эфффективным методом 
профилактики и лечения невынашивания у женщин с многоплодной беременностью, снижения частоты позднего аборта и преждевременных родов, перинатальных потерь. Установлено, что у женщин основной группы уровни АЛТ и АСТ, а также общего билирубина не отклонялись от нормы. Отмечено снижение уровня прогестерона в обеих подгруппах. У беременных Іа подгруппы на фоне лечения микронизированным прогестероном отмечалось существенное повышение уровня

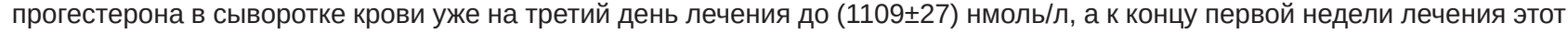

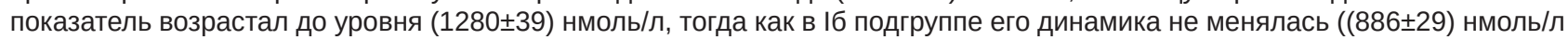

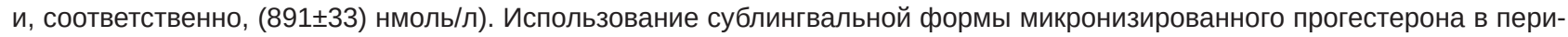
од выраженной клинической симптоматики угрозы преждевременных родов при многоплодной беременности позволяет получить максимально быстрый терапевтический эффрект, способствует быстрому устранению клинических симптомов, регрессу ультразвуковых маркеров угрозы прерывания беременности и предотвращает дальнейшее прогрессирование структурных изменений со стороны шейки матки.

Выводы. 1. При признаках угрозы преждевременных родов применение сублингвальной формы микронизированного прогестерона дает возможность быстро восстановить уровень прогестерона в сыворотке крови до фризиологических показателей и тем самым снизить частоту преждевременных родов и улучшить перинатальные исходы у новорожденных. 2. Применение сублингвальной формы микронизированного прогестерона у беременных с угрозой преждевременных родов не влияет на функцию печени. 3. Комплексная терапия угрозы преждевременных родов с использованием микронизированного прогестерона имеет высокую эфффективность терапевтического действия и может быть рекомендована для широкого использования, способствует укорочению периода пребывания в стационаре, уменьшению количества осложнений.

Ключевые слова: многоплодная беременность; невынашивание; сублингвальная форма микронизированного прогестерона (Лютеина); вагинальная форма микронизированного прогестерона; угроза преждевременных родов.

POSSIBILITIES OF THE TREATMENT OF PRETERM LABOR OF MULTIPLE PREGNANCY BY THE USE OF SUBLINGUAL FORMS OF MICRONIZED PROGESTERONE

The aim of the study - to evaluate the effectiveness of the application of the sublingual form of micronized progesterone (Lutein) in women with multiple pregnancies with a high risk of premature birth.

Materials and Methods. We examined 85 women pregnant with twins with signs of miscarriage in the period of 22 to 36 weeks of gestation, which made the main group, two subgroups were formed: la - 43 women, received micronized progesterone sublingually in a complex of treatment of the threat of termination of pregnancy; subgroup $\mathrm{lb}-42$ pregnant women who did not receive progesterone medication during treatment. Retrospectively, 40 stories of preterm labor were analyzed in a single pregnancy (comparison group). In the main group, a general clinical and biochemical examination of pregnant women, determination of serum levels of ALT, AST, levels of bilirubin and progesterone was carried out. The analysis of the course of pregnancy, childbirth, the postpartum period and the state of neonatal adaptation of newborns in the examined pregnant women.

Results and Discussion. We proved major risk factors for premature birth in multiple pregnancies, as well as the role of infectious anamnesis, of data the transvaginal cervicometry, incomplete examination and untimely initiation of treatment of the threat of premature birth, insufficient prevention of complications in multiple pregnancies. The dynamics of cervical contraction was significantly slower in la subgroup of patients who received micronized progesterone, this is an effective method of preventing and treating miscarriage in women with multiple pregnancies, reducing the frequency of late abortion and premature birth, and perinatal loss. It was found that in women of the main group ALT and AST levels, as well as total bilirubin, did not deviate from the norm. A decrease in the level of progesterone in both subgroups was noted. In pregnant women of la subgroup, against the backdrop of treatment with micronized progesterone, a significant increase in the serum level of progesterone was observed on the third day of treatment to $(1109 \pm 27) \mathrm{nmol} / \mathrm{L}$, and by the end of the first week of treatment, this index increased to $(1280 \pm 39) \mathrm{nmol} / \mathrm{l}$, while in Ib subgroup its dynamics did not change $(886 \pm 29) \mathrm{nmol} / \mathrm{I}$ and, accordingly, (891 \pm 33$) \mathrm{nmol} / \mathrm{l})$. The use of sublingual forms of micronized progesterone in the period of severe clinical symptoms of the threat of premature labor in multiple pregnancies makes it possible to obtain the fastest therapeutic effect, facilitates rapid elimination of clinical symptoms, regression of ultrasound markers of the threat of termination of pregnancy and prevents further progression of structural changes from the cervix.

Conclusions. 1. With signs of the threat of premature delivery of the sublingual form of micronized progesterone, it is possible to quickly restore the serum level of progesterone to physiological indices, thereby reducing the incidence of premature births by and perinatal outcomes in newborns. 2. The use of sublingual form of micronized progesterone in pregnant women with preterm labor does not affect the function of the liver. 3. Complex therapy of the threat of preterm labor with the use of micronized progesterone has a high effectiveness of therapeutic action and can be recommended for wide use, shortens the period of stay in the hospital, reduces the number of complications.

Key words: multiple pregnancy; miscarriage; sublingual form of micronized progesterone (Lutein); the vaginal form of micronized progesterone; threat of preterm labor.

ВСтУП. У сучасному акушерстві відсоток дострокового переривання вагітності, на жаль, не знижується, згідно з даними медичної статистики, показник частоти передчасних пологів сягає у розвинених країнах 7,5-12 \%, у Європі - 5-9 \%, в Україні - 15-23\% [1, 2]. Пріоритетним напрямком у поліпшенні демографрічних показників є проорілактика передчасних пологів [3, 4]. Передчасні пологи $€$ головною причиною перинатальних втрат, високої захворюваності та інвалідизації (до 50 \%) новонароджених
$[6,9]$. Частота анте-, інтра- та перинатальної смертності серед недоношених новонароджених у 15-30 разів перевищує цей показник для дітей, народжених вчасно. Приблизно 50 \% недоношених новонароджених залишаються глибокими інвалідами (прояви респіраторного дистрес-синдрому (РДС), внутрішньошлуночкових крововиливів, тяжкої ретинопатії та ін.) [9, 10]. Невиношування вагітності $€$ найчастішим ускладненням гестаційного процесу у жінок із багатопліддям. Частота передчасних 
пологів при багатоплідді становить 54,3 \% порівняно 3 $12 \%$ при одноплідній вагітності [8, 9]. Втрачені вагітності складають майже 17 \% від усіх бажаних вагітностей, при цьому 75-80 \% викиднів трапляються на ранніх термінах, i, на жаль, відсутня тенденція до зниження цих показників $[2,10,11]$. Питання щодо природи і механізмів розвитку загрози передчасних пологів при багатоплідді не можна вважати цілком вирішеним, а отже, відсутні і чіткі патогенетично обґрунтовані принципи лікування цієї патології, тому це є предметом подальших досліджень.

У реалізації синдрому невиношування вагітності при багатоплідді бере участь цілий ланцюг петогенетичних фракторів, до них відносяться плацентарна дисфункція, істміко-цервікальна недостатність, інфекційно-запальний процес, імунні реакції та вроджені чи набуті тромбофрілії, екстрагенітальні захворювання, нейроендокринні порушення, більшість 3 яких супроводжується гестагенною недостатністю, починаючи ще на етапі прегравідарної підготовки [7, 8]. Основні причини самовільного переривання вагітності: недостатність жовтого тіла вагітності при первинному зниженні вмісту прогестерону. На сьогодні не існує ефективного способу профілактики передчасних пологів при багатоплідній вагітності. Схеми лікування включають токолітичну та спазмолітичну терапію, просрілактику синдрому дихальних розладів, гормональну терапію препаратами прогестерону та метаболічну терапію. В останні роки все більше уваги у разі загрози передчасних пологів приділяють застосуванню препаратів прогестерону, оскільки він пригнічує експресію генів, які відповідають за скоротливу активність міометрія, перешкоджає передчасному вкороченню шийки матки, що призводить до зниження частоти дострокового завершення вагітності $[6,7,10,11]$.

Британські фрахівці провели дослідження з оцінки значення прогестерону у профрілактиці передчасних пологів при двійні (STOPPIT - Study Of Progesterone for the Prevention of Preterm Birth In Twins). Були зроблені висновки, що застосування прогестерону при двійні не знижує частоту передчасних пологів або внутрішньоутробної загибелі плода до 34 тижнів вагітності, що може пояснюватись недостатнім дозуванням прогестерону [11]. Прогестерон - один з основних гормонів, що відповідають за збереження вагітності, сприяє посиленню кровоплину в матці, блокує синтез рецепторів окситоцину, транспорт іонів у міоцитах, тим самим знижує тонус матки, знижує транспорт іонів кальцію в цитоплазму міоцитів, завдяки цьому інгібує проходження електричного імпульсу, що ініціює маткові скорочення. Згідно з останніми науковими даними, прогестерон пригнічує експресію генів, що відповідають за скоротливу активність міометрія, $\epsilon$ антагоністом простагландину $\mathrm{F} 2 \alpha$, інгібує активність простагландинів шляхом пригнічення їх попередника арахідонової кислоти. Основний механізм, що сприяє збереженню вагітності, пов'язаний $з$ імунологічними особливостями вагітності - прогестероніндукованим блокуючим фрактором (PIBF). Він виробляється у присутності достатньої кількості прогестерону й перешкоджає відторгненню плідного яйця, котре містить чужорідні для матері антигени батька, і сприймається в якості алотрансплантата [10, 11].

На сьогодні існує багато різноманітних форм препаратів прогестерону, але одним із найбільш вдалих за швидкістю дії та безпечністю є сублінгвальна фрорма мікро- нізованого прогестерону - препарат «Лютеіна» (Адамед, Польща), що є повністю ідентичною ендогенному гормону. Створює максимальну концентрацію в плазмі крові та органах-мішенях, не зазнає первинного метаболізму в печінці, що дозволяє досягти максимальної концентрації в крові при низьких дозуваннях та обрати найбільш зручний шлях введення. На відміну від інших фрорм прогестерону, добре переноситься пацієнками у будь-якому терміні гестації, має високу біодоступність, безпечність у використанні. При довготривалому застосуванні не впливає на параметри функцій печінки, ліпідний профріль сироватки крові, рівні ФСГ, ЛГ, кортизолу, альдостерону. Сублінгвальна форма $\epsilon \in$ єиною у світі унікальною формою натурального мікронізованого прогестерону, котра $€$ незаперечною альтернативою пероральним формам прогестерону, що пов'язано з відсутністю печінкового метаболізму. Застосування сублінгвальної форми мікронізованого прогестерону дає можливість швидко - за 30-60 хв досягти максимальної концентрації у плазмі крові $((17,9 \pm 2,8)$ нг/мл) при мінімальній медикаментозній агресії, оскільки відсутній ефект первинного проходження через печінку, здійснює усунення клінічних симптомів та регрес ультразвукових маркерів загрози переривання вагітності, сприяє коротшому періоду перебування у стаціонарі, кількість ускладнень менша на 50 \% порівняно з іншими гестагенами $[9,10,11]$.

Встановлено, що на фроні застосування мікронізованого прогестерону ризик передчасних пологів у терміні до 34 тижнів вагітності знижується на $42 \%$, крім того, достовірно знижуються показники захворюваності та смертності новонароджених, розвитку респіраторного дистрес-синдрому (РДС) до 52-61 \%, потреби у штучній вентиляції легень (R. Romero і співавт., 2012) [11].

Проте, незважаючи на доведену в низці клінічних досліджень високу есрективність терапії загрози передчасних пологів препаратами прогестерону, питання призначення мікронізованого прогестерону, вибору найбільш оптимальної форми введення препарату та тривалості лікування залишається дискутабельним.

МЕТА ДОСЛІДЖЕННЯ - оцінити ефективність застосування сублінгвальної фрорми мікронізованого прогестерону (Лютеіна) у жінок із багатоплідною вагітністю 3 високим ризиком загрози передчасних пологів.

МАТЕРІАЛИ ТА МЕТОДИ. Наукове дослідження проводилось на базі Сумського обласного клінічного перинатального центру протягом 2015-2017 років. Обстежено 85 вагітних із двійнятами з ознаками невиношування у термінах 22-36 тижні вагітності, котрі склали I - основну групу. Критеріями включення була наявність клінічних ознак загрози передчасних пологів у вагітних двійнею: підвищення тонусу матки, біль унизу живота, попереку, структурні зміни шийки матки - розм'якшення, вкорочення, згладжування; ультразвукові: підвищення тонусу матки, вкорочення та дилятація шийки матки за даними трансвагінальної цервікометрії; лабораторно: зниження концентрації прогестерону в сироватці крові. Критерії виключення: екстрагенітальна патологія, рубець на матці, пацієнтки з встановленими структурними та хромосомними аномаліями плода, а також з монохоріальними двійнятами у зв'язку з високим ризиком розвитку синдрому фето-фретальної гемотрансфузії (СФФТ) та можливою необхідністю дострокового розродження. Проведення дослідження було схвалено комісією з питань медичної 
етики після підписання поінформованої згоди щодо проведення досліджень.

Залежно від застосованого методу лікування було сорормовано дві підгрупи: Іа - 43 жінки, котрі отримували протягом 48 год токолітичну терапію ніфедипіном за схемою гострого токолізу з продовженням лікування до 48 год у дозі 20 мг кожні 8 год та дексаметазон за схемою згідно 3 діючими клінічними протоколами (наказ МОЗ України від 03.11.2008 р. № 624). 3 першої доби мікронізований прогестерон застосовували сублінгвально по 100 мг 3 рази на добу, з третьої доби мікронізований прогестерон сублінгвально по 100 мг 2 рази на добу, за наявност показань - вводили розвантажувальний акушерський песарій. У підгрупу Іб були включені 42 вагітні, які отримували токолітичну терапію ніфедипіном за схемою гострого токолізу, з продовженням лікування до 48 год у дозі 20 мг кожні 8 год та дексаметазон для профрілактики РДС у новонароджених за загальноприйнятою схемою, з третьої доби призначали прифрінію бромід по 30 мг 3 рази на добу перорально, розвантажувальний акушерський песарій - за показаннями.

Усі вагітні обстежені згідно з наказами МОЗ України від 31.12.2004 р. № 676 та від 03.11.2008 р. № 624. Нами було вивчено загальний, соматичний, акушерсько-гінекологічний анамнез, перебіг вагітності, пологів, динаміку стану шийки матки при прогресуванні багатоплідної вагітності. Крім клінічних методів обстеження та загальноприйнятих лабораторних досліджень, з метою оцінки загрози передчасних пологів проводилась трансвагінальна цервікометрія, а також оцінка стану шийки матки за Штембергом, де сума балів 5 і вища була показанням для профрілактики і лікування загрози переривання вагітності.

Проведений аналіз перебігу вагітності, пологів, післяпологового періоду та стану неонатальної адаптації новонароджених в обстежуваних вагітних. Оцінка стану плода проводилась за допомогою ультразвукового дослідження та кардіотокографії; оцінювання новонароджених - за шкалою Апгар, масо-зростовими показниками, клінічними даними; окрім того, проводилося визначення вмісту у сироватці крові аланінамінотранссрерази (АЛТ), аспартатамінотрансорерази (АСТ), загального білірубіну, рівня прогестерону.

Ретроспективно було проаналізовано 40 історій передчасних пологів при одноплідній вагітності (II група - порівняння). Статистичну обробку отриманих даних проводили параметричними методами з використанням комп'ютерних статистичних програм [5]. Статистичні дані цитовані з дисертаційної роботи Ірини Миколаївни Нікітіної «Затримка розвитку плода у вагітних, зайнятих у виробництві суперфосфрату (прогнозування, профрілактика та лікування)», захищеної у 2010 р. В дисертаційній роботі дані оброблялися 3 застосуванням варіаційностатистичного методу аналізу отриманих результатів за допомогою персонального комп'ютера IBM PC Intel Celeron $^{\mathrm{TM}} 556$ МГц та прикладної програми роботи 3 електронними таблицями Microsoft $®$ Exel 97 у середовищі Windows Millenium. Статистичну обробку матеріалу проводили методами варіаційної та парної статистики, а також застосовували метод відмінності з використанням t-критерію Стьюдента. Отримані результати вважали достовірними, якщо коефіцієнт достовірності р, який знаходили по таблиці Стьюдента, був меншим 0,05.
РЕЗУЛЬТАТИ ДОСЛІДЖЕННЯ ТА ЇХ ОБГОВОРЕННЯ.

Пацієнтки у групах не відрізнялися за віком і масо-зростовими показниками та соціальним станом. Середній вік обстежуваних основної групи складав 26-36 років - 73,8 \%, молодших 18 років - 4,7\%, понад 36 років - 13,8\%. Переважна більшість жінок були мешканками міста (понад $65 \%$ ) та домогосподарками (59 \%). За паритетом половина жінок 3 I групи були першовагітними (55,2 \%), решта жінок мали повторні вагітності, з них у 17 попередні вагітності закінчились нормальними пологами, у 21 - в анамнезі мали місце самовільні викидні та штучні аборти. У групі порівняння першовагітних жінок - $60 \%$.

У структурі екстрагенітальної патології в обох групах жінок переважали гострі респіраторні захворювання під час вагітності, гіпертензивні розлади, нейроциркуляторна дистонія, патологія нирок. Серед гінекологічних захворювань спостерігались ерозія шийки матки у 67,5 \%, запальні захворювання статевих органів - у 45,3 \%, порушення менструального циклу - у 21,7 \% пацієнток, лейоміома матки - у 6,8%. У кожної другої пацієнтки в анамнезі відзначено наявність урогенітальної інфекції.

Аналізуючи акушерський анамнез, слід зазначити, що частота репродуктивних втрат і штучних абортів в обох групах була досить високою, що стало серйозним чинником ризику розвитку ускладнень при даній вагітності. Оцінка результатів перебігу вагітності та пологів виявила найчастіші гестаційні ускладнення, зокрема в обох групах найчастіше перебіг вагітності супроводжувався тривалою загрозою ії переривання, анемією, плацентарною диссункцією, прееклампсією, наявністю урогенітальних інфекцій.

Ретроспективний аналіз історій пологів виявив недоліки в обстеженні, такі, як: пізнє взяття на облік, недооцінка анамнестичних даних та фракторів ризику гестаційних ускладнень, неповне обстеження, несвоєчасний початок лікування загрози переривання вагітності, а також недостатня профрілактика та лікування ускладнень вагітності: анемії, гіпертензивних розладів та прееклампсії, урогенітальних іноекцій, наслідком яких був розвиток передчасних пологів у різні терміни вагітності та висока перинатальна смертність недоношених новонароджених.

Під час госпіталізації практично всі обстежувані вагітні скаржились на ниючий чи переймоподібний біль внизу живота чи попереку, мажучі кров'янисті виділення зі статевих шляхів. У процесі лікування спостерігався більш швидкий регрес клінічної симптоматики загрози переривання вагітності у Іа підгрупі обстежуваних вже на 1-шу добу, у Іб підгрупі - на 2-гу добу, на 3-тю добу лікування больові відчуття відзначали 40 \% жінок Іа групи, у той час у Іб групі цей показник був достовірно вищий $(p<0,01)$ і становив 57,5 \%. Отримані результати пов'язані зі швидкою дією сублінгвальної форми мікронізованого прогестерону. На 5-ту добу клінічна симптоматика зберігалась у 10,0\% вагітних Іа підгрупи, 22,5 \% - у Іб підгрупі (рис. 1).

Регрес УЗ-маркерів (нормалізація товщини міометрія, регрес ретрохоріальної гематоми, звуження просвіту цервікального каналу та сповільнення динаміки вкорочення шийки матки) було відзначено на $(3,2 \pm 0,5)$ та $(4,0 \pm 0,3)$ доби відповідно.

Аналіз клінічних результатів застосування методу лікування та профрілактики невиношування у вагітних із багатопліддям із застосуванням натурального мікронізованого прогестерону поданий у таблиці 1. 

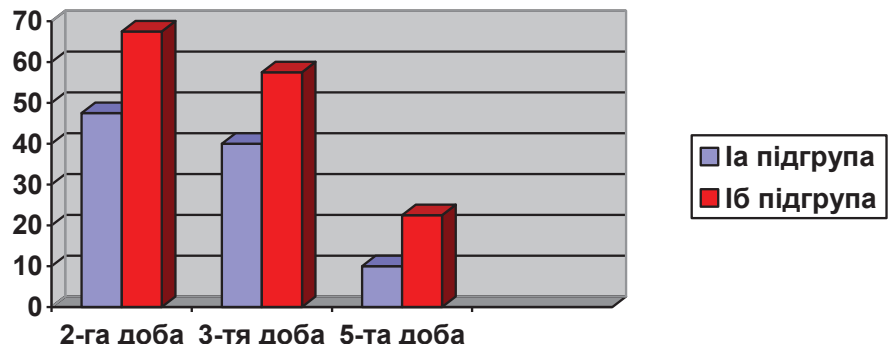

Рис. 1. Динаміка клінічних симптомів в обстежуваних вагітних.

Таблиця 1. Аналіз клінічних результатів застосування лікування

\begin{tabular}{|l|c|c|c|c|c|}
\hline Група обстеження & Кількість жінок & $\begin{array}{c}\text { Зменшення клініч- } \\
\text { них симптомів 3ПВ, } \\
\text { доба }\end{array}$ & $\begin{array}{c}\text { Регрес } \\
\text { У3-маркерів 3ПВ, } \\
\text { день }\end{array}$ & $\begin{array}{c}\text { ПРПО, кількість ви- } \\
\text { падків, \% }\end{array}$ & $\begin{array}{c}\text { Тривалість перебуван- } \\
\text { ня в стаціонарі, дні }\end{array}$ \\
\hline б підгрупа & 42 & $2,0 \pm 1,2^{\star}$ & $4,0 \pm 0,3^{*}$ & $11(26,2 \%)^{*}$ & $18 \pm 1,6^{*}$ \\
\hline Іа підгрупа & 43 & $1,0 \pm 1,0$ & $3,2 \pm 0,5$ & $7(16,2 \%)$ & $12 \pm 1,2$ \\
\hline
\end{tabular}

Примітка. * - показник достовірності між групами.

Під час проведення біохімічного дослідження кров рівні показників фрункціонального стану печінки (АЛТ, АСТ, загальний білірубін, непрямий білірубін) у всіх вагітних основної групи знаходилися у рамках референтних значень, що свідчило про відсутність порушень з боку печінки під час лікування в обстежуваних вагітних. Встановлено, що в жінок основної групи, як у тих, котрі отримували прогестерон, так і у Іб підгрупи, у лікуванні яких не використовували гестагени, рівні АЛТ та АСТ, а також загального білірубіну практично не змінювались: на момент госпіталізації у підгрупі Іа рівень АСТ становив $(31,3 \pm 4,2)$ нмоль/л, у підгрупі Іб - $(32,3 \pm 3,6)$ нмоль/л, на третю добу лікування у Іа підгрупі - $(29,8 \pm 4,5)$ нмоль/л, у Іб - $(31,3 \pm 4,2)$ нмоль/л, а до кінця першого тижня лікування у Іа підгрупі - $(30,4 \pm$ $4,2)$ нмоль/л, у Іб - $(31,3 \pm 4,3)$ нмоль/л. Рівень АЛТ теж був

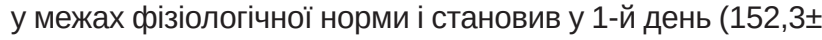
$9,2)$ нмоль/л (проти $(154,1 \pm 10,2)$ нмоль/л у підгрупі Іб), на третю добу - $(154,2 \pm 10,4)$ нмоль/л $((162,4 \pm 9,2)$ нмоль/л у підгрупі Іб), на сьому добу - $(159,7 \pm 9,2)$ нмоль/л (у підгрупі Іб - $(163,3 \pm 11,2)$ нмоль/л). Концентрація загального

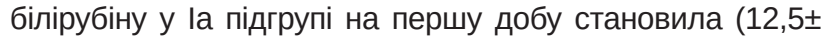

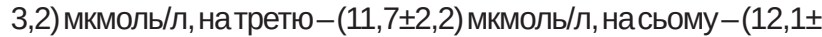
1,2) мкмоль/л; відповідно, у Іб підгрупі - $(11,7 \pm 4,2)$ мкмоль/л, $(13,4 \pm 4,2)$ мкмоль/л, $(12,5 \pm 4,2)$ мкмоль/л. Ці показники доводять відсутність негативного впливу мікронізованого прогестерону на функцію печінки.
Відмічено зниження сироваткового рівня прогестерону в обох підгрупах. На момент госпіталізації з загрозою передчасних пологів в обох підгрупах концентрація прогестерону не відрізнялася і в середньому складала в підгрупі Іа

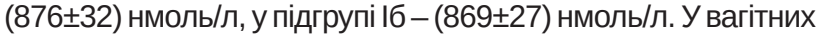
Іа підгрупи на тлі лікування мікронізованим прогестероном відмічалося суттєве зростання рівня прогестерону у сиро-

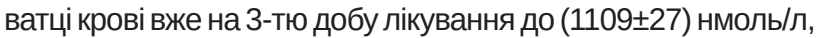
а до кінця першого тижня лікування цей показник зростав до

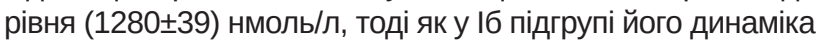

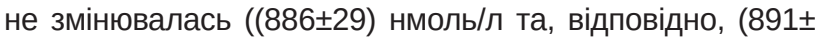
33) нмоль/л) (рис. 2).

Ці показники свідчать про високу ефективність та швидке відновлення концентрації прогестерону у жінок із загрозою передчасних пологів при сублінгвальному застосуванні мікронізованого прогестерону.

Основними ознаками регресу УЗ-маркерів були відсутність прогресування вкорочення шийки та прогресивного збільшення діаметра внутрішнього зіва поряд із зникненням гіпертонусу матки. У Іа підгрупі на 3-тю добу у 7,5 \% вагітних довжина шийки матки зменшилась до 20-25 мм, а у 2,5 \% діаметр внутрішнього вічка збільшився до 3 мм, у Іб підгрупі ця негативна динаміка була прогресивнішою і склала 12,5 \% вагітних, у яких довжина шийки матки була $<25$ мм. На 5-ту та 7-му доби не помітили прогресування вкорочення шийки матки у вагітних Іа підгрупи, проте у Іб

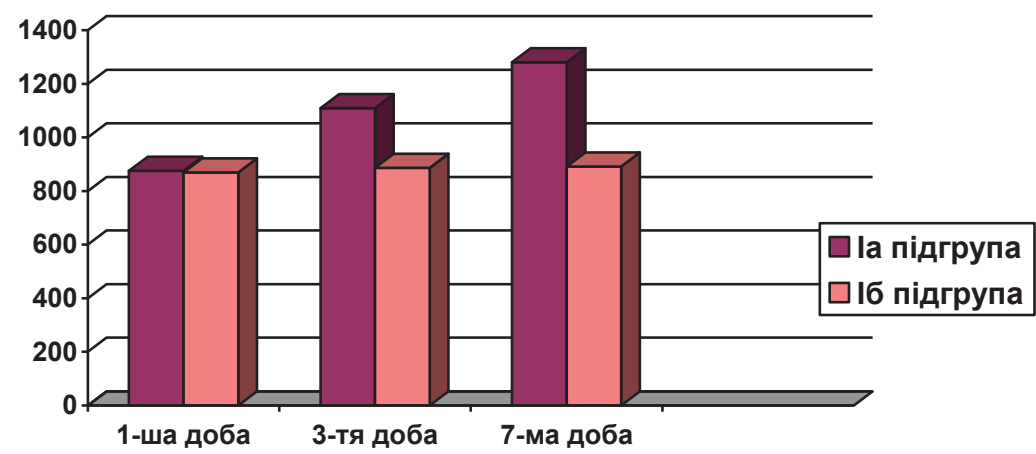

Рис. 2. Динаміка вмісту прогестерону в сироватці крові в обстежуваних вагітних. 
підгрупі кількість жінок із довжиною шийки матки <25 мм зросла, відповідно, на 7,5\%.

В Іа підгрупі обстежуваних термінові пологи відбулися у 34 (79 \%) випадках, у Іб підгрупі - у 29 (69 \%) випадках. Перебіг пологів ускладнився передчасним розривом плодових оболонок (ПРПО) у 7 (16,2\%) пацієнток Іа підгрупи, в 11 (26,2 \%) жінок Іб підгрупи, безводний проміжок не перевищував $(7,8 \pm 1,5)$ год та $(12,4 \pm 2,3)$ год відповідно $(p<0,05)$. Ceредня тривалість пологів склала $(10,4 \pm 2,3)$ год у Іа підгрупі та $(8,6 \pm 1,5)$ год - у Іб підгрупі. Патологічної крововтрати під час пологів через природні пологові шляхи у жінок основної групи та групи порівняння не було.

Розродження шляхом кесарського розтину було проведено в 1 (2,3 \%) вагітної Іа підгрупи, у 4 (9,5 \%) пацієнток Іб підгрупи. У Іа підгрупі кесарський розтин проведено у плановому порядку, показанням було тазове передлежання першого плода з двійні. У Іб підгрупі операція була проведена у плановому порядку у двох випадках, в решті випадків проведена ургентна операція кесарського розтину з приводу передчасного відшарування плаценти у I періоді пологів та дистресу плода. У групі порівняння планові операції були проведені у двох випадках з приводу тазового передлежання плода, у трьох випадках був проведений ургентний кесарський розтин з приводу дистресу плода в пологах у терміні 36 тижнів вагітності, передчасного відшарування плаценти та з приводу випадіння петель пуповини.

Тривалість перебування в стаціонарі склала в середньому $(12 \pm 1,2)$ дня в жінок Іа підгрупи, $(18 \pm 1,6)$ дня у Іб підгрупі та $(18 \pm 1,3)$ дня в обстежуваних групи порівняння $(p<0,05)$.

При вивченні стану неонатальної адаптації новонароджених обстежуваних груп були отримані наступні результати. Середня вага новонароджених Іа підгрупи склала

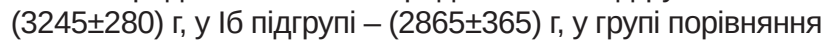

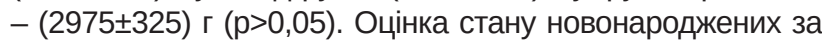
шкалою Апгар, відповідно на 1-й та на 5-й хвилинах, була: у новонароджених Іа підгрупи $(7,5 \pm 1,4)$ та $(8,2 \pm 1,3)$ балів, у
Іб підгрупі - $(6,4 \pm 1,6)$ та $(7,5 \pm 1,1)$ балів, у групі порівняння - $(6,1 \pm 1,9)$ та $(7,0 \pm 1,8)$ балів (p1-p2 >0,05).

Отже, використання сублінгвальної фрорми мікронізованого прогестерону у період вираженої клінічної симптоматики загрози передчасних пологів при багатоплідній вагітності дозволяє отримати максимально швидкий терапевтичний ефект, що сприяє швидкому усуненню клінічних симптомів, регресу ультразвукових маркерів загрози переривання вагітності та запобігає подальшому прогресуванню структурних змін з боку шийки матки.

ВИСНОВкИ. Таким чином, за результатами проведеного дослідження можна зробити такі висновки:

1. При ознаках загрози передчасних пологів застосування сублінгвальної фрорми мікронізованого прогестерону дає можливість швидко відновити рівень прогестерону в сироватці крові до фрізіологічних показників і тим самим знизити частоту передчасних пологів та покращити перинатальні наслідки у новонароджених.

2. Застосування сублінгвальної фрорми мікронізованого прогестерону у вагітних із загрозою передчасних пологів не впливає на фуннцію печінки.

3. Комплексна терапія загрози передчасних пологів із використанням мікронізованого прогестерону має високу есрективність терапевтичної дії та може бути рекомендована для широкого використання, сприяє коротшому періоду перебування в стаціонарі, зменшенню кількості ускладнень.

ПЕРСПЕКТИВИ ПОДАЛЬШИХ ДОСЛІДЖЕНЬ ПОлягають у поглибленні вивчення проблеми застосування різних фрорм мікронізованого прогестерону для профрілактики передчасних пологів. Отримані результати показали ефективність застосування сублінгвальної фрорми мікронізованого прогестерону з метою просрілактики і лікування загрози передчасних пологів у жінок із багатоплідною вагітністю, попередження розвитку можливих ускладнень під час вагітності, в пологах та перинатальних ускладнень.

\section{СПИСОК ЛІТЕРАТУРИ}

1. Баранов И. И. Перинатальные исходы при многоплодных родах / И. И. Баранов, 3. 3. Токова, А. А.Тадевосян // Акушерство и гинекология. - 2012. - № 1. - С. 98-102.

2. Багатоплідна вагітність : навч. посіб. Ч. II (для викладача) / ред. : Ю. П. Вдовиченко, Н. Г. Гойда, О. М. Юзько. - K., 2011. - 360 c.

3. Жук С. І. Ефективне попередження передчасних пологів: від науки до практики / С. І. Жук // Жіночий лікар. 2013. - № 1 (45). - С. 4.

4. Современные проблемы многоплодной беременности / В. И. Краснопольский, С. В. Новикова, М. В. Капустина [и др.] // Российский вестник акушера-гинеколога. - 2009. № 2. - С. 79-81.

5. Лапач С. Н. Статистические методы в медико-биологических исследованиях с использованием «Exel» / С. Н. Лапач, А. В. Чубенко, П. Н. Бабич. - К. : Морион, 2000. - 320 с.

6. Каминский В. В. Применение прогестерона в акушерской практике / В. В. Каминский, Л. Н. Онищук // Збірник наукових праць Асоціації акушерів-гінекологів України. - 2015. - № 1 (35). - C. 5-12.
7. Резніченко Г. І. Профрілактика невиношування вагітності і передчасних пологів / Г. І. Резніченко // Жіночий лікар. 2013. - № 3. - С. 10-14.

8. Особливості неонатальної адаптації новонароджених $з$ двійні / І. М. Нікітіна, А. Б. Сухарєв, А. В. Бойчук, С. А. Сміян // Журнал клінічних та експериментальних медичних досліджень. - 2016. - Т. 4, № 2. - С. 264-271.

9. Spontaneous and non-spontaneous twins: a comparasion study of preterm labor, preterm premature rupture of membranes, gestational age at delivery, maternal age, and len th of hospital stay / L. Almonte, M. Davis, C. Ward [et al.] // Twin Research and Human Genetics. - 2012. - Vol. 15, No. 2. - P. 170.

10. Effect of progesterone treatment due to threatened abortion in early pregnancy for obstetric and perinatal outcome / L. Duan, D. Yan, W. Zeng [et al.] // Early Human Development. - 2010. - No. 6. - P. 41-43.

11. Effectiveness of progestogens to improve perinatal outcome in twin pregnancies: an individual participan data meta-analisis / E. Schuit, S. Stock, L. Rode [et al.] // BJOG. 2015. - Vol. 122 (1), - P. 27-37. doi: 10.1111/1471-0528.13032. 
REFERENCES

1. Baranov, I.I., Tokova, Z.Z., \& Tadevosyan, A.A. (2012). Perinatalnye iskhody pri mnogoplodnykh rodakh [Perynatal result of multiple pregnancy]. Akusherstvo i ginekologiya Obstetrics and Ggynecology, 1, 98-102 [in Russian].

2. Vdovychenko, Yu.P. (2011). Bahatoplidna vahitnist: navchalnyi posibnyk [Multifeded pregnancy: a manual. Ch. II (for the teacher))]. Vdovychenko, Yu.P., Hoyda, N.H., \& Yuzko, O.M. (Eds.). Kyiv [in Ukrainian].

3. Zhuk, S.I. (2013). Efektyvne poperedzhennia peredchasnykh polohiv: vid nauky do praktyky [Effective prevention of preterm labor: the bifid of science to practice] Zhinochyi likar - Woman's Doctor, 1, (45) [in Ukrainian].

4. Krasnopolskiy, V.I., Novikov, D.M., Kapustin, S.F., Titchenko, L.I., Aksenov, A.N., \& Zharova, A.A. (2009). Sovremennyye problemy mnogoplodnoy beremennosti [Modern problems of multiple pregnancy]. Rossiyskiy vestnik akusheraginekologa - Russian Bulletin of Obstetrician Gynecologist, 2 , 79-81 [in Russian].

5. Lapach, S.N., Chubenko, A.V., \& Babych, P.N (2000). Statistycheskye metody $v$ mediko-biologicheskikh issledovanyyakh s ispolzovanyem "Exel" [Statistical methods in biomedical research using "Exel"]. Kyiv: Morion [in Russian].

6. Kaminskiy, V.V., \& Onishchuk, L.N. (2015). Primeneniye progesterona v akusherskoy praktike [Application of progesterone in obstetric practice]. Zbirnyk naukovykh prats Asotsiatsii akusheriv-hinekolohiv Ukrainy - Collection of Scientific Works of the Association of Obstetricians-Gynecologists of Ukraine, 1 (35), 5-12 [in Russian]

7. Reznichenko, G.I. (2013). Profilaktyka nevynoshuvannia vahitnosti i peredchasnykh polohiv [Prevention of miscarriage and premature delivery]. Zhinochyi likar - Woman's Doctor, 3 , 10-14 [in Ukrainian].

8. Nikitina, I.N., Sukharev, A.B., Boichuk, A.V., \& Smiian, S.A. (2016). Osoblyvosti neonatalnoi adaptatsii novonarodzhenykh z dviini [Features of adaptation neonatal infants from twins]. Zhurnal klinichnykh ta ekperymentalnykh doslidzhen - Journal of Clinical and Experimental Medical Research, (4), 2, 264- 271 [in Ukrainian].

9. Almonte, L., Davis, M., Ward, C., Brown, D., \& Craparo, F. (2012). Spontaneous and non-spontaneous twins: a comparasion study of preterm labor, preterm premature rupture of membranes, gestational age at delivery, maternal age, and len th of. Twin Research and Human Genetics, (15), 2, 170.

10. Duan, L., Yan, D., Zeng, W., Yang, X., \& Wei, Q. (2010). Effect of progesterone treatment due to threatened abortion in early pregnancy for obstetric and perinatal outcome. Early Human Development, 6, 41-43.

11. Schuit, E., Stock, S., Rode, L. Rouse, D.J., Lim, A.C., Norman, J.E. ... Global Obstetrics Network (GONet) collaboration. (2015). Effectiveness of progestogens to improve perinatal outcome in twin pregnancies: an individual participan data metaanalisis. British Journal of Obstetrics and Gynecology, 122 (1), 27-37. doi: 10.1111/1471-0528.13032. 